\title{
ХИМИЧЕСКИЙ СОСТАВ ПОДЗЕМНЫХ ВОД РЕЖИМНЫХ ВОДОПРОЯВЛЕНИЙ ПЕТРОПАВЛОВСКОГО ГЕОДИНАМИЧЕСКОГО ПОЛИГОНА, КАМЧАТКА: ТИПИЗАЦИЯ И ЭФФЕКТЫ СИЛЬНЫХ ЗЕМЛЕТРЯСЕНИЙ
}

\author{
(С) 2018 г. Г. Н. Копылова ${ }^{1, *}$ * Н. В. Гусева², Ю. Г. Копылова², С. В. Болдина ${ }^{1}$ \\ ${ }^{1}$ Камчатский филиал Федерального исследовательского центра “Единая геофизическая служба РАН” \\ 683006 Петропавловск-Камчатский, бульвар Пийпа, 9, Россия \\ ${ }^{2}$ ФГАОУ ВО “Национальный исследовательский Томский политехнический университет” \\ 634050 Томск, проспект Ленина, 30, Россия \\ *e-mail: gala@emsd.ru \\ Поступила в редакцию 30.08.2017 г.
}

\begin{abstract}
Рассматриваются особенности химического состава и типизация подземных вод семи самоизливающихся скважин и четырех источников с использованием материалов гидрогеохимического опробования в 2014 г. и данных режимных наблюдений КФ ФИЦ ЕГС РАН в 1989-1999 гг. Приводятся оценки насыщенности подземных вод отдельных водопроявлений алюмосиликатными, карбонатными, сульфатными вторичными минералами, прослежены ее изменения во времени. Обнаружено увеличение насыщенности подземных вод вторичными минералами при сильных землетрясениях, сопровождавшихся сотрясениями с интенсивностью I = 5-6 баллов по шкале MSK-64. На стадиях подготовки землетрясений такие изменения насыщенности подземных вод вторичными минералами проявляются в меньшей степени. Обсуждаются перспективы развития системы наблюдений на скважинах и источниках в целях поиска новых видов гидрогеохимических предвестников землетрясений.
\end{abstract}

DOI: $10.1134 / \mathrm{S} 0203030618040041$

\section{ВВЕДЕНИЕ}

С 1977 г. проводятся наблюдения за химическим составом подземных вод из самоизливающихся скважин и источников на территории Петропавловского геодинамического полигона, Камчатка, с целью поиска гидрогеохимических предвестников и разработки методов прогнозирования землетрясений. В изменениях концентраций макрокомпонентов в составе подземных вод и свободного газа были зафиксированы аномалии в связи с сильными местными землетрясениями, в т. ч. гидрогеохимические предвестники за недели-месяцы до их возникновения [Копылова и др., 1994; Копылова, Болдина, 2012; Хаткевич, Рябинин, 2004]. Вместе с тем, вопрос о механизмах формирования таких аномалий недостаточно изучен в геохимическом аспекте. Необходимость его всестороннего рассмотрения обусловлена тем, что адекватное понимание процессов формирования гидрогеохимических эффектов сейсмичности с использованием данных по составу подземных вод будет способствовать оптимальной организации специализированных наблюдений на скважинах и источниках в сейсмоактивных регионах.
Изучение аномалий состава подземных вод из скважин и источников при землетрясениях на основе фундаментальных закономерностей их формирования в системах вода-горная порода дает возможность их содержательного объяснения. Впервые реализация такого подхода была продемонстрирована в работе [Копылова и др., 2014], в которой аномалия состава воды из скважины Морозная-1 в период землетрясения 2 марта 1992 г., $M=6.9$ рассматривалась с использованием методов равновесной термодинамики и анализа элементарных химических реакций, проходящих в системе вода-порода [Гаррелс, Крайст, 1968]. Принимая, что начальными продуктами таких реакций являются породообразующие минералы и вода и конечными продуктами - вторичные минералы, а также поступающие в подземную воду ионы и нейтральные молекулы, и с использованием количественного параметра - индекса неравновесности подземной воды к вторичным минералам (или показателя А, по [Зверев, 1982]) было показано изменение насыщенности воды вторичными минералами не только на постсейсмической стадии, но и на стадии подготовки землетрясения. Уравнения взаимодействия вод с 
алюмосиликатными, карбонатными и сульфатными минералами, их основные термодинамические параметры и описание методики расчетов приводятся в работе [Копылова и др., 2014, http://www.kscnet.ru/ivs/publication/volc_day/2014/ art29.pdf]. Такой подход к интерпретации данных наблюдений за химическим составом подземных вод направлен на развитие гидрогеохимического метода поиска предвестников землетрясений в части обоснования совокупности информативных показателей для каждой наблюдательной скважины.

В 2014 г. выполнено обследование районов расположения гидрогеохимических станций Пиначево, Верхняя Паратунка, Морозная и Хлебозавод (рис. 1) с отбором проб воды из 11-ти режимных водопроявлений. В работе представлены данные о химическом составе воды скважины ГК-1 и четырех источников станции Пиначево, скважин Морозная-1 (М-1) и Г-1 (станция Хлебозавод) и четырех скважин станции Верхняя Паратунка (ГК-5, ГК-15, ГК-17, ГК-44) по результатам опробования в 2014 г. и по материалам гидрогеохимических наблюдений Камчатского филиала Федерального исследовательского центра “Единая геофизическая служба РАН” (КФ ФИЦ ЕГС РАН) в 1989-1999 гг.

Химический анализ отобранных в 2014 г. проб воды с определением в них макро- и микрокомпонентов производился в Проблемной научноисследовательской лаборатории гидрогеохимии Научно-образовательного центра "Вода" Томского политехнического университета. Данные химанализов представлены в таблицах 1 и 2, диаграммы химического состава - на рис. 2.

Оценка насыщенности подземных вод режимных водопроявлений к основным породообразующим минералам проводилась путем нанесения данных на диаграммы полей устойчивости алюмосиликатных минералов (рис. 3) и расчета параметра насыщенности (SI) по отношению к алюмосиликатным, карбонатным и сульфатным минералам при температуре $25^{\circ} \mathrm{C}$ [Гаррелс, Крайст, 1968] (рис. 4): $\mathrm{SI}=\lg (Q / K \mathrm{p})$, где $Q-$ квотант реакций или отношение фактического произведения активностей продуктов реакции к фактическому произведению активности исходных веществ, Кр - константа реакции. Положительные значения SI свидетельствуют о насыщенности вод вторичными минералами, и, по мере насыщения вод вторичными минералами, величина SI увеличивается (в отличие от ранее используемого в работе [Копылова и др., 2014] показателя А), что является более наглядным при интерпретации результатов гидрогеохимических наблюдений.

С использованием материалов режимных наблюдений 1989-1999 гг. КФ ФИЦ ЕГС РАН были рассчитаны изменения во времени параметров SI по отношению к вторичным алюмосиликатным минералам, кальциту, ангидриту и др. в сопоставлении с произошедшими землетрясениями с величинами магнитуд порядка 7 и более, сопровождавшихся 5-6 балльными сотрясениями по шкале MSK-64 в районах наблюдательных станций (рис. 5-7, см. рис. 1).

\section{Характеристика района и гидрогеохимических эффектов землетрясений}

Геолого-тектонические условия района определяются его расположением в зоне контакта Тихоокеанской океанической и Евразийской континентальной литосферных плит. Граница между ними проходит в области Курило-Камчатского глубоководного желоба (см. рис. 1). Здесь происходит погружение океанической плиты под полуостров Камчатка в северо-западном направлении до глубин 600 км. Верхняя часть погружающейся плиты и вышерасположенные структуры континентальной плиты маркируются скоплением гипоцентров землетрясений с максимальными величинами магнитуд до 8-9, образовывающих Камчатский фрагмент Курило-Камчатской сейсмофокальной зоны [Федотов и др., 1985].

Территория Петропавловского геодинамического полигона расположена в центральной части Камчатского фрагмента Курило-Камчатской островной дуги и находится на пересечении Малко-Петропавловской складчато-глыбовой зоны поперечных дислокаций и наложенных Восточно-Камчатского и Южно-Камчатского вулканических поясов [Геология ..., 1964]. Район характеризуется интенсивной тектонической активностью и повышенным тепломассообменом в пределах земной коры и верхней мантии, сопровождающихся проявлениями современного вулканизма и гидротермальной деятельности. На рассматриваемой территории расположены действующие вулканы Авачинский, Корякский, Мутновский, Горелый и термопроявления Паратунской, Пиначевской и Кеткинской гидротермальных систем [Гидрогеология ..., 1972].

Формирование водных ресурсов района происходит, в основном, за счет инфильтрации талых ледниковых вод и атмосферных осадков [Кирюхин и др., 2015]. По условиям циркуляции подземных вод в районе выделяются три гидродинамические зоны [Манухин, 1971]: 1 - верхняя зона свободного водообмена холодных вод в рыхлых покровных отложениях четвертичного возраста и в породах региональной зоны экзогенной трещиноватости магматических и уплотненных вулканогенно-осадочных пород позднемелового-неогенового возраста; 2 - зона относительно затрудненного водообмена в пределах погруженных участков Авачинской вулканотектонической депрессии и структурных депрессий Петропавловского горста, сложенных уплотненными и слабометаморфизо- 


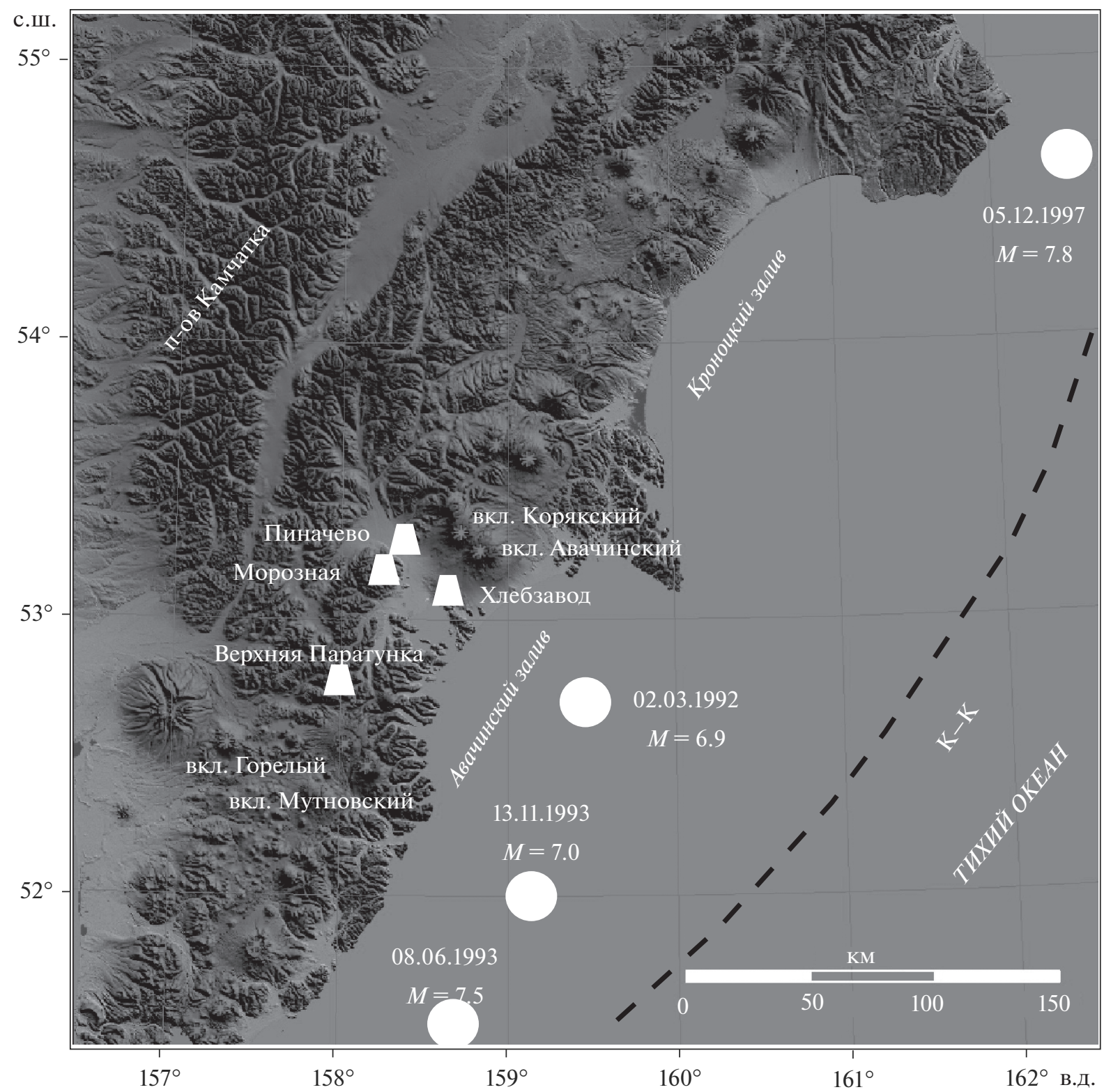

Рис. 1. Схема расположения гидрогеохимических станций КФ ФИЦ ЕГС РАН на территории Петропавловского геодинамического полигона и эпицентров сильных землетрясений (показаны кружками) с указанием их даты (дд. мм. гггг) и величины магнитуды $M . \mathrm{K}-\mathrm{K}$ - ось Курило-Камчатского глубоководного желоба, по которой проходит граница Тихоокеанской океанической и Евразийской континентальной литосферных плит.

ванными вулканогенно-осадочными и терригенными образованиями позднемелового-неогенового возраста; 3 - зона активного водообмена термальных вод в пределах Паратунской, Пиначевской и Кеткинской гидротермальных систем.

Сейсмичность. За время наблюдений наиболее сильными сейсмическими событиями вблизи территории Петропавловского полигона были четыре землетрясения (см. рис. 1), сопровождавшиеся сотрясениями с интенсивностью $I=5-6$ баллов по шкале MSK-64 в районах наблюдательных станций. В результате сотрясений от этих землетрясе- ний проявлялись аномалии в изменениях концентраций макрокомпонентов состава воды и газа из водопроявлений станций Пиначево, Морозная, Верхняя Паратунка и Хлебозавод (постсейсмические эффекты). В скважинах ГК-1, М-1 и Г-1 были зарегистрированы аномалии в изменениях концентраций макрокомпонентов состава воды перед землетрясениями (гидрогеохимические предвестники).

Ниже приводится краткое описание станций с учетом материалов обследования 2014 г. и выявленных ранее гидрогеохимических эффектов 


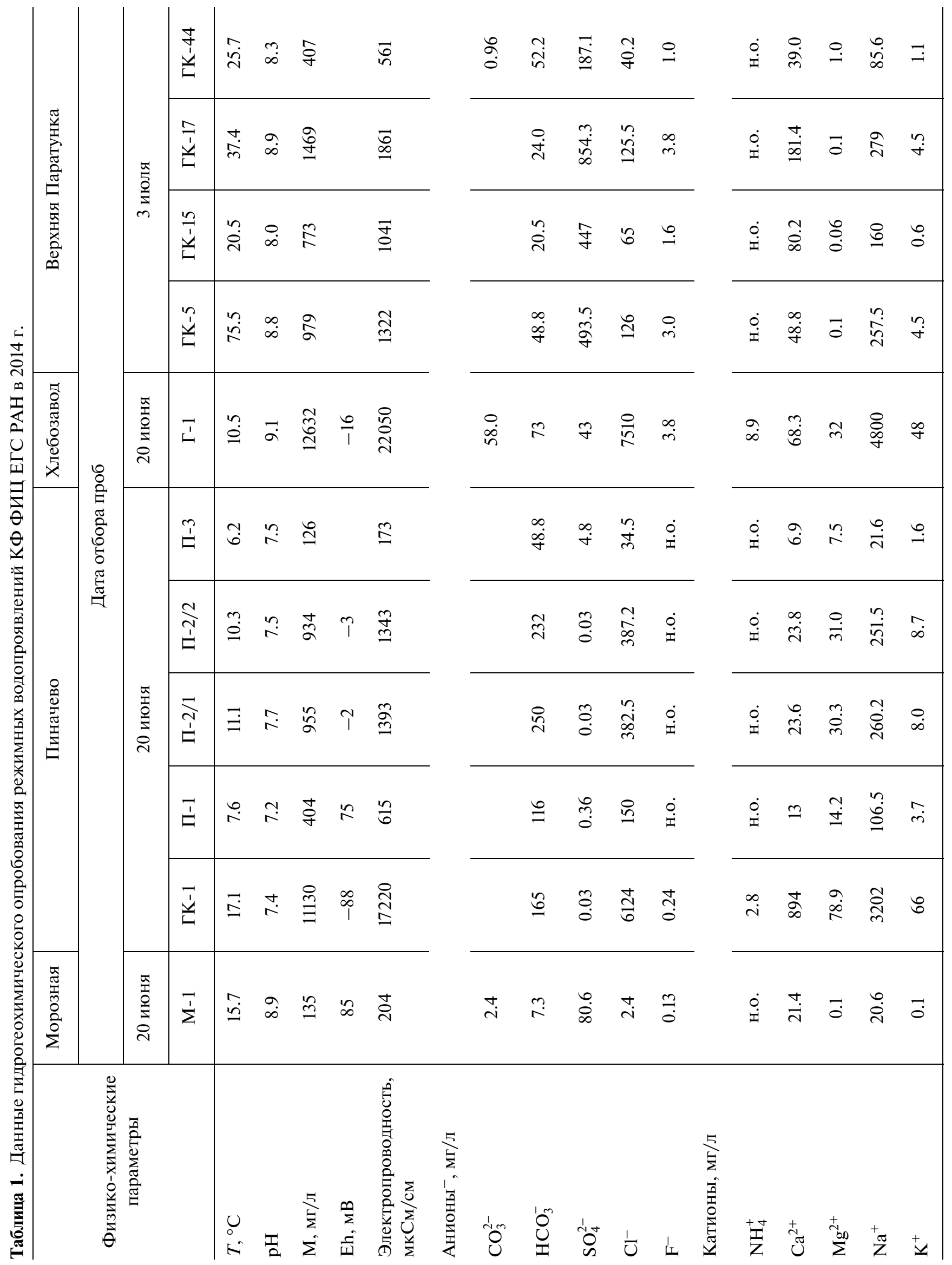




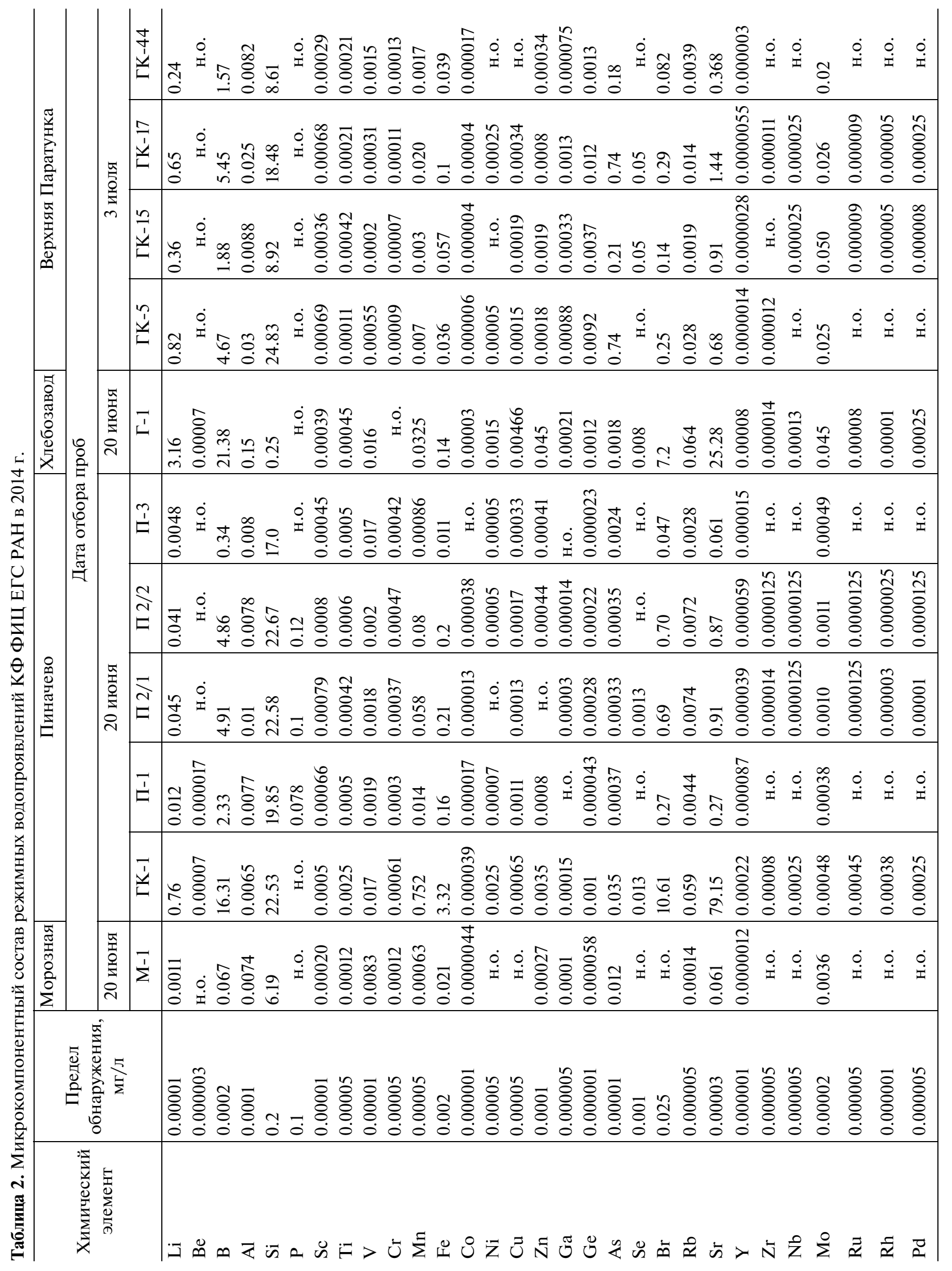




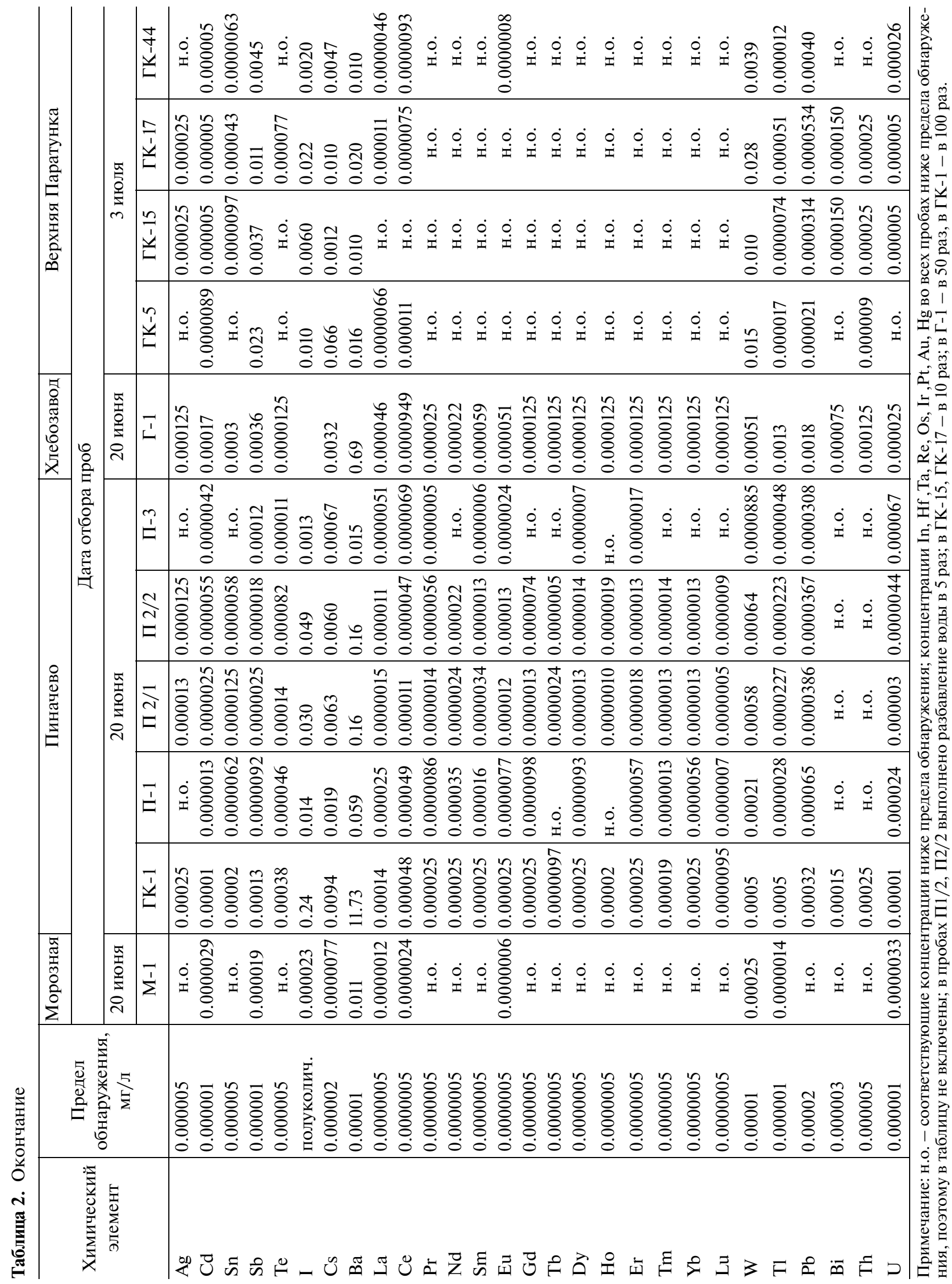



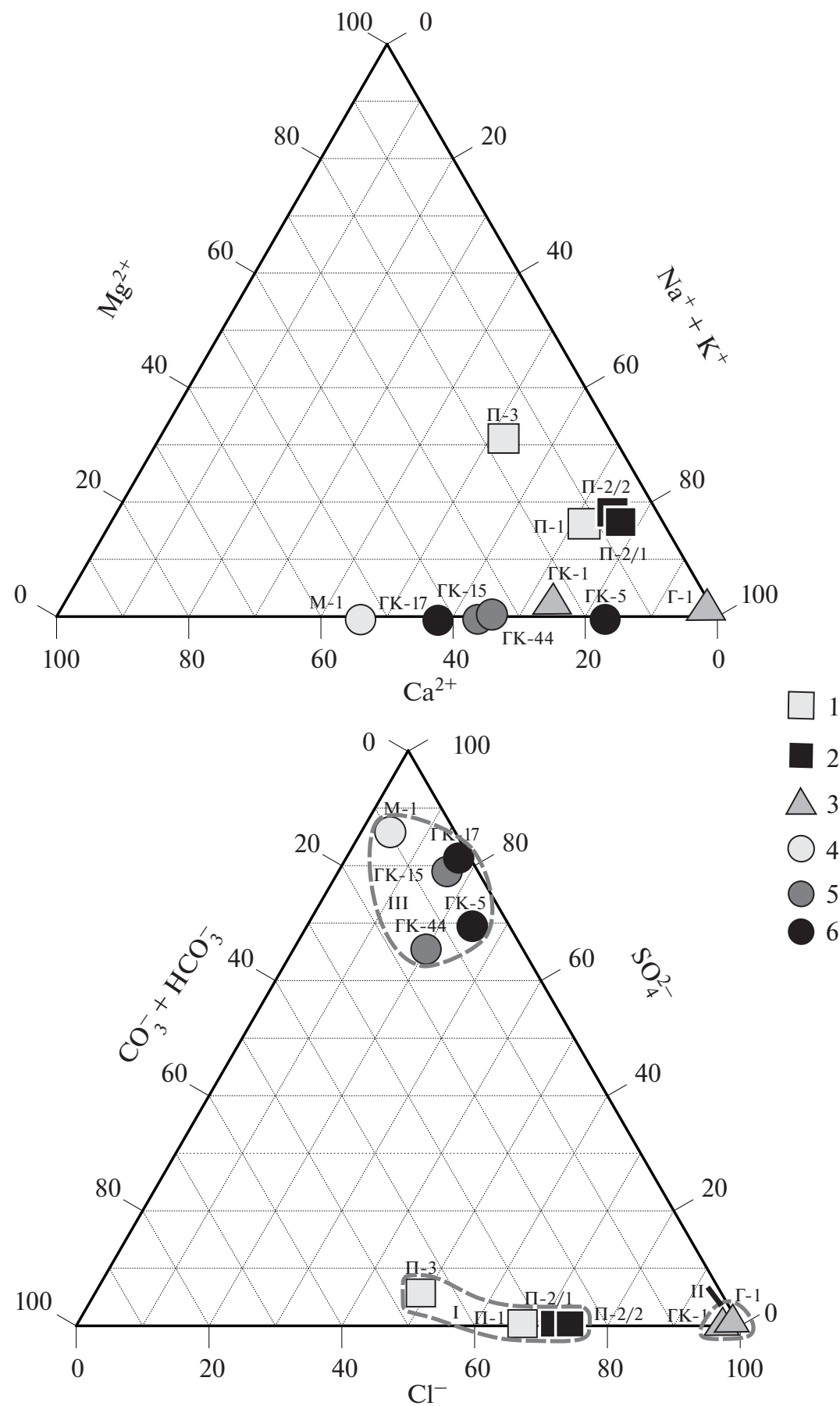

Рис. 2. Диаграммы химического состава вод из источников и самоизливающихся скважин Петропавловского геодинамического полигона.

1 - порово-трешинные и трешинные пресные холодные воды источников П-3 и П-1, ст. Пиначево; 2 - трешинные пресные субтермальные воды источников П-2/1 и П-2/2, ст. Пиначево; 3 - трещинные и трещинно-жильные соленые субтермальные воды скважины ГК-1, ст. Пиначево и скважины $\Gamma-1$, ст. Хлебозавод; 4 - трещинно-жильные ультрапресные субтермальные воды скважины М-1, ст. Морозная; 5 - трещинно-жильные пресные субтермальные воды скважин ГК-44 и ГК-15, ст. Верхняя Паратунка; 6 - трещинно-жильные солоноватые термальные воды скважин ГК17 и ГК-5, ст. Верхняя Паратунка; I, II, III - выделенные группы вод (см. текст).

сильных землетрясений по [Копылова и др., 1994; Хаткевич, Рябинин, 2004].

Станция Пиначево расположена у подножия Пиначевского экструзивного массива андезида- цитов и включает самоизливающуюся скважину ГК-1 глубиной 1261 м и четыре источника П-1, П-2/1, П-2/2, П-3. Режимные водопроявления расположены в зоне разгрузки азотно-метановых 
(a)

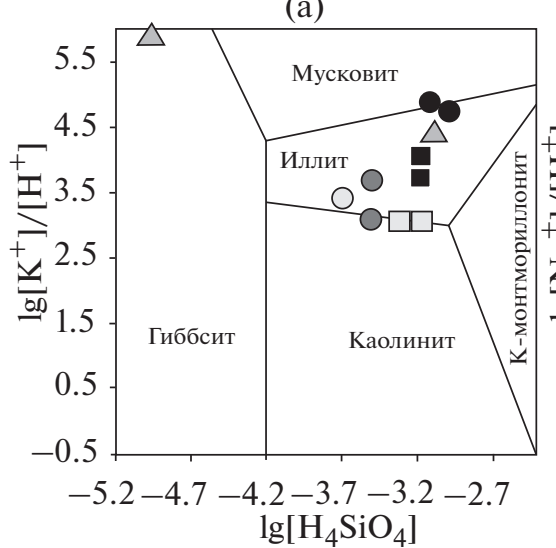

(г)

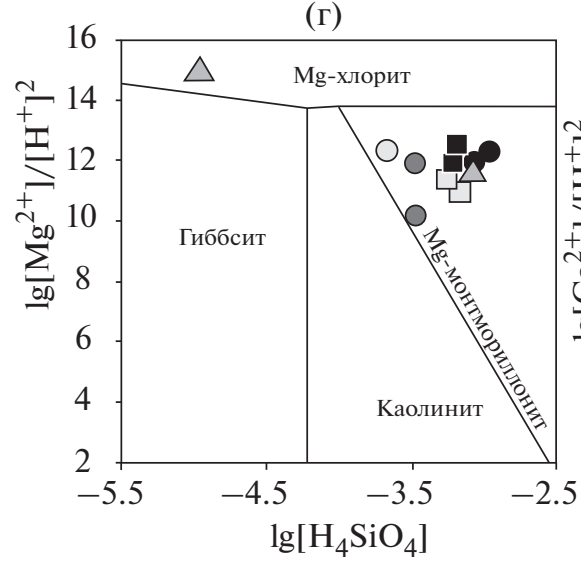

(б)

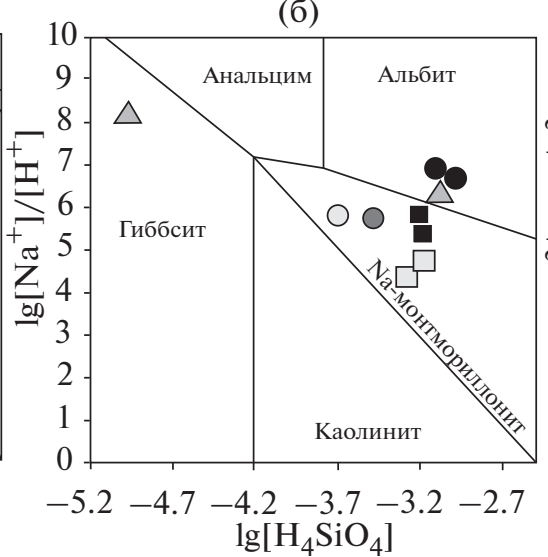

(д)

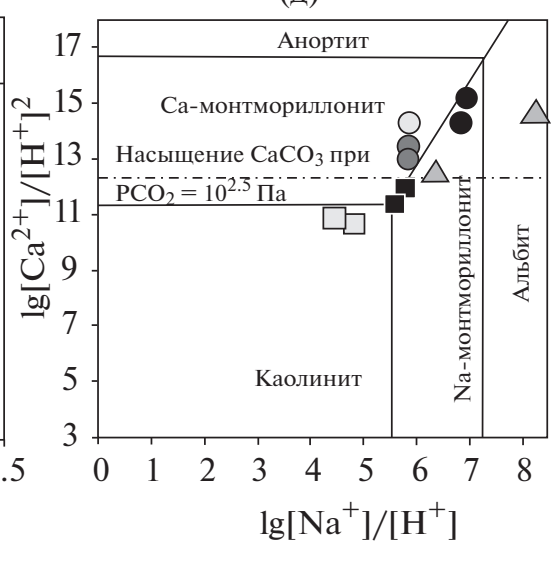

(в)

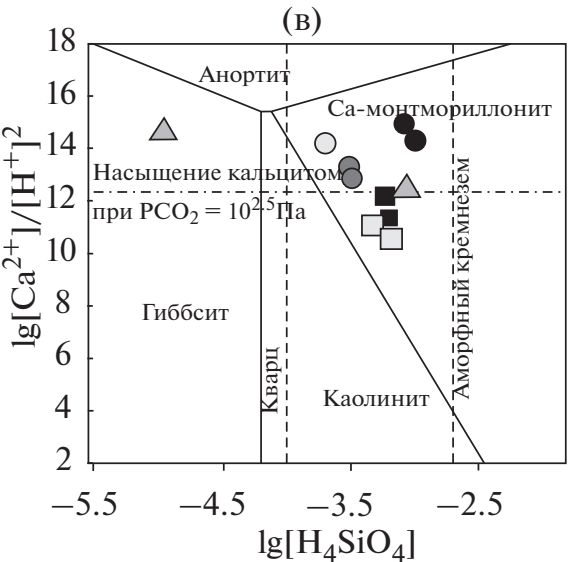

(e)

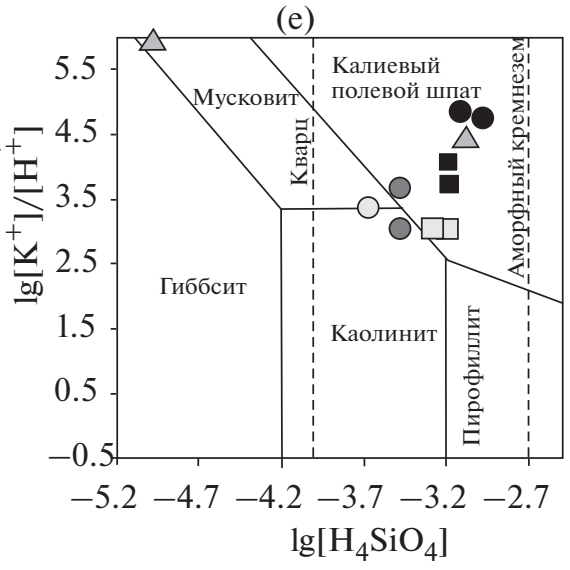

$\square 1 \bullet 2 \triangle 3 \circ 4 \circ 5 \bullet 6$

Рис. 3. Диаграммы равновесия подземных вод с алюмосиликатными минералами при температуре $25^{\circ} \mathrm{C}$. a - мусковит-иллит-K-монтмориллонит-каолинит-гиббсит; б - анальцим-альбит-Nа-монтмориллонит-каолинит-гиббсит; в - анортит-Са-монтмориллонит-каолинит-гиббсит; г - Mg-хлорит-Мg-монтмориллонит-каолинит-гиббсит; д - анортит-альбит-Ca-монтмориллонит-Na-монтмориллонит-каолинит; е - мусковит-КПШ-пирофиллит-каолинит-гиббсит. Условные обозначения см. рис. 2.

хлоридных кальциево-натриевых термальных вод Пиначевской гидротермальной системы, распространенных в андезидацитах экструзивного массива и в вулканогенных, вулканогенно-осадочных и осадочных отложениях четвертичного, позднепалеоген-неогенового и позднемелового возраста Авачинской вулканотектонической депрессии. В структурном плане разгрузка источников и локализация многочисленных аномалий химического состава подземных и поверхностных вод контролируется глубинным Петропавловским разломом северо-западного простирания и оперяющими его зонами повышенной трещиноватости [Поляк и др., 1965; Копылова, 1992].

Скважина ГК-1, пробуренная примерно в 100 м от источников, вскрыла в диапазоне глубин 4001260 м напорные хлоридные кальциево-натриевые воды с минерализацией 11.1 г/л. Ее дебит составляет 0.1 л/с. Состав свободного газа из скв. ГК-1 азотно-метановый $\left(\mathrm{CH}_{4}-80\right.$ об. \%, $\mathrm{N}_{2}-20$ об. \%).

Химический состав воды источников изменяется от гидрокарбонатного кальциево-магниевого до гидрокарбонатно-хлоридного натриевого и определяется различной степенью разбавления восходящего потока хлоридных кальциево-натриевых термальных вод пресными холодными водами, распространенными в рыхлых четвертичных отложениях и в зоне выветривания андезидацитов. Минерализация воды источников 0.1-1.0 г/л, температура $-6-11^{\circ} \mathrm{C}$, дебиты $-0.1-$ 0.4 л/с. В составе свободного газа преобладает азот $\left(\mathrm{N}_{2} \geq 75\right.$ об. \%, $\mathrm{CH}_{4} \leq 25$ об. \%).

В связи с сильными землетрясениями (см. рис. 1) в изменениях химического состава воды скв. ГК-1 проявлялись гидрогеохимические предвестники в уменьшении концентраций макрокомпонентов $\mathrm{Cl}^{-}, \mathrm{Na}^{+}$и $\mathrm{Ca}^{2+}$, сменявшимся их увеличением после землетрясений (постсейсми- 

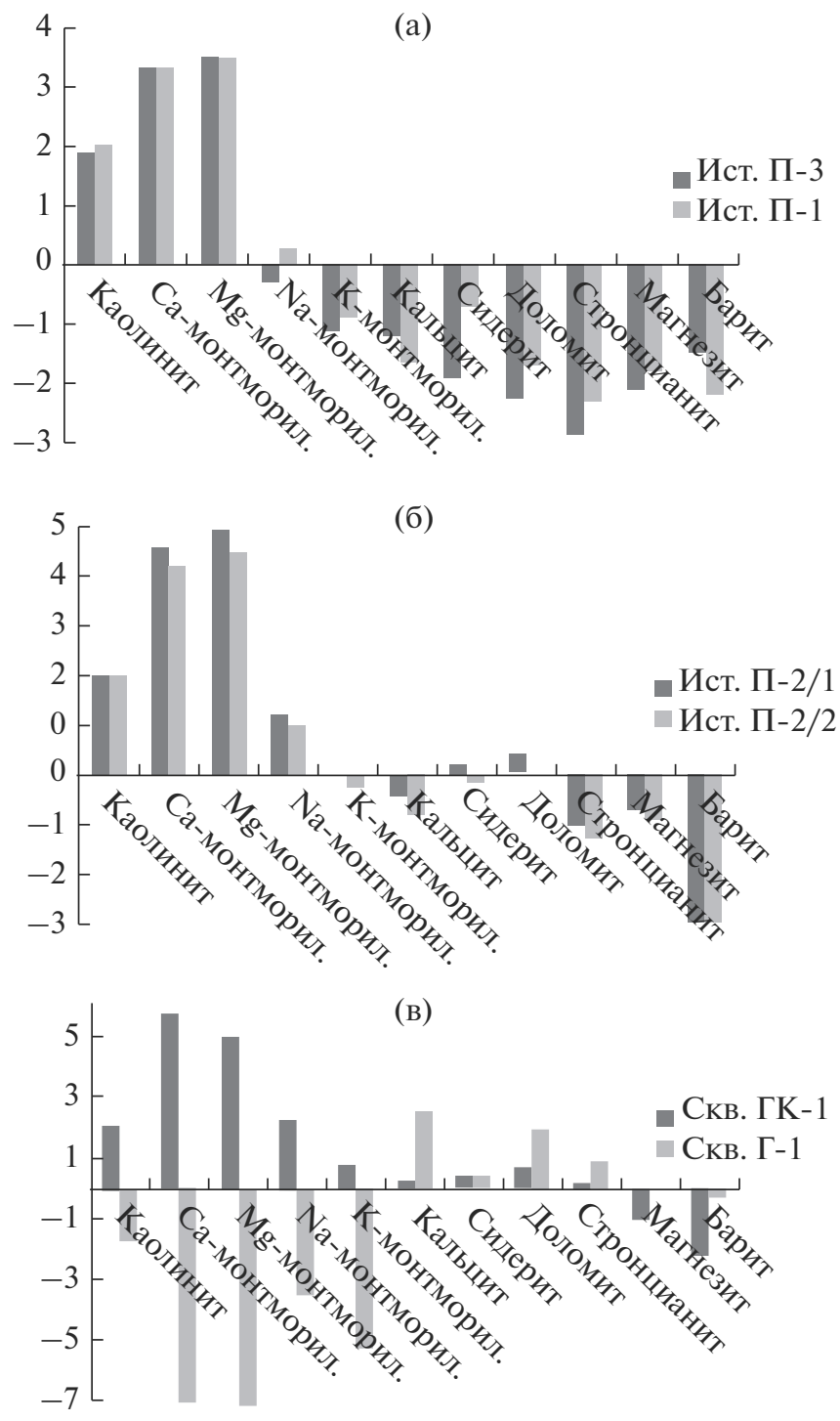

(г)

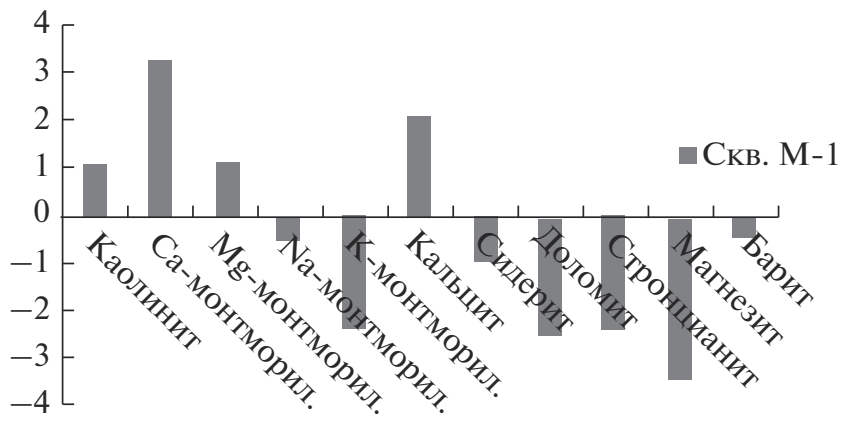

(д)

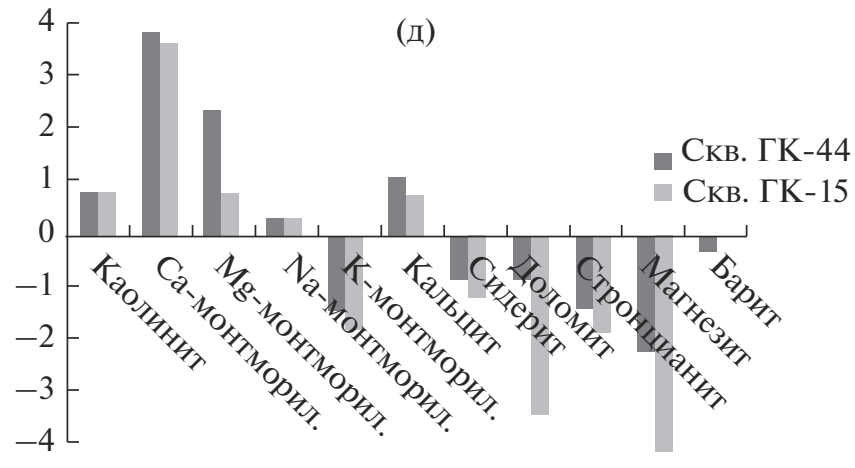

(e)

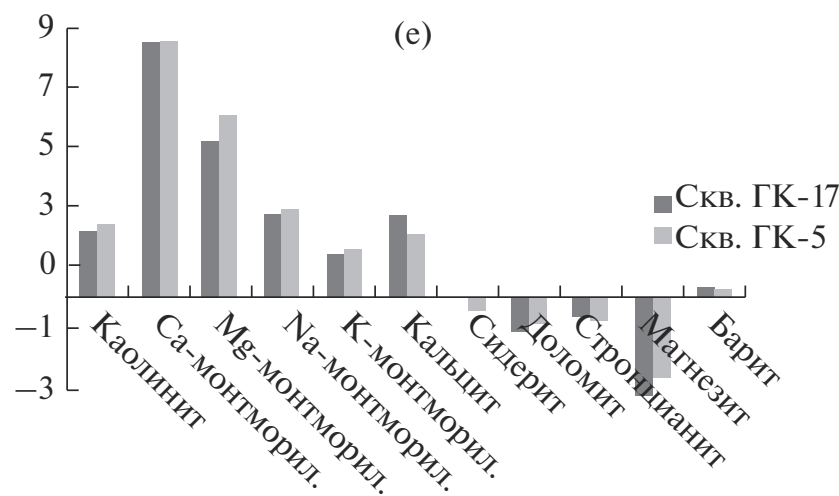

Рис. 4. Величины параметров насыщенности подземных вод различных типов алюмосиликатными, карбонатными и сульфатными минералами.

a - грунтовых порово-трещинных пресных гидрокарбонатно-хлоридных холодных вод источников П-3 и П-1, ст. Пиначево; б - трещинных пресных гидрокарбонатно-хлоридных субтермальных вод источников П-2/1 и П-2/2, ст. Пиначево; в - трещинных и трещинно-жильных соленых хлоридных субтермальных вод скважин ГК-1, ст. Пиначево и $\Gamma-1$, ст. Хлебозавод; г - трещинно-жильных ультрапресных сульфатных субтермальных вод скважины М-1, ст. Морозная; д - трещинно-жильных пресных сульфатных субтермальных вод скважин ГК-44 и ГК-15, ст. Верхняя Паратунка; е - трещинно-жильных солоноватых сульфатных термальных вод скважин ГК-17 и ГК-5, ст. Верхняя Паратунка.

ческий эффект). Продолжительности предвестников и постсейсмических эффектов составляли несколько месяцев. В изменениях химического состава воды источников наблюдалось постсейсмическое увеличение концентраций $\mathrm{Cl}^{-}, \mathrm{HCO}_{3}^{-}$, $\mathrm{Na}^{+}, \mathrm{Ca}^{2+}, \mathrm{Mg}^{2+}$ и др.

Станция Хлебозавод. Самоизливаюшаяся скв. Г-1 вскрывает на глубинах 1710-2424 м азотно-метановые хлоридные натриевые воды с минерализацией 12.6 г/л, распространенные в битуми- низированных осадочных отложениях позднемелового возраста, слагающих локальную депрессию в пределах Петропавловского горста. Дебит скважины составляет менее 0.01 л/с. В составе воды скв. Г-1 перед и после землетрясения 5 декабря 1997 г., $M=7.8$ наблюдалось изменение концентраций макрокомпонентов $\mathrm{Cl}^{-}$и $\mathrm{Na}^{+}$[Хаткевич, Рябинин, 2004].

Станция Морозная. Скв. М-1 расположена в пределах Начикинской зоны складчато-глыбо- 


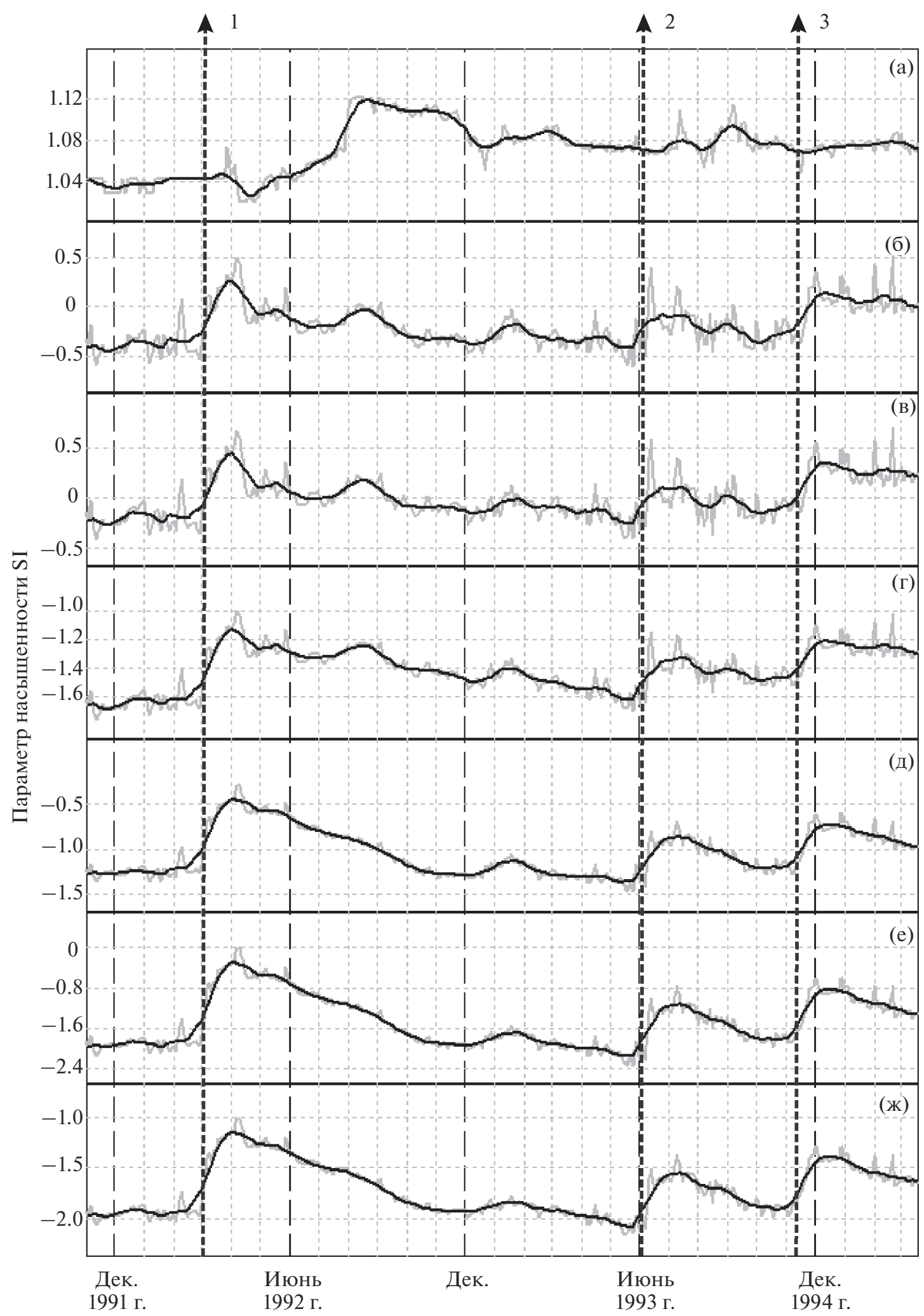

Рис. 5. Изменение насыщенности подземной воды источника П-1, ст. Пиначево к каолиниту (а), Са-монтмориллониту (б), Mg-монтмориллониту (в), Na-монтмориллониту (г), кальциту (д), доломиту (е), магнезиту (ж) в 1991-1994 гг. Черными линиями показано осреднение расчетных значений индексов насыщенности в скользящем временном окне длиной 30 сут с шагом 3 сут. Вертикальные стрелки - землетрясения: $1-2$ марта 1993 г., $M=6.8 ; 2-8$ июня 1993 г., $M=$ $=7.5 ; 3-13$ ноября 1993 г., $M=7.0$. 


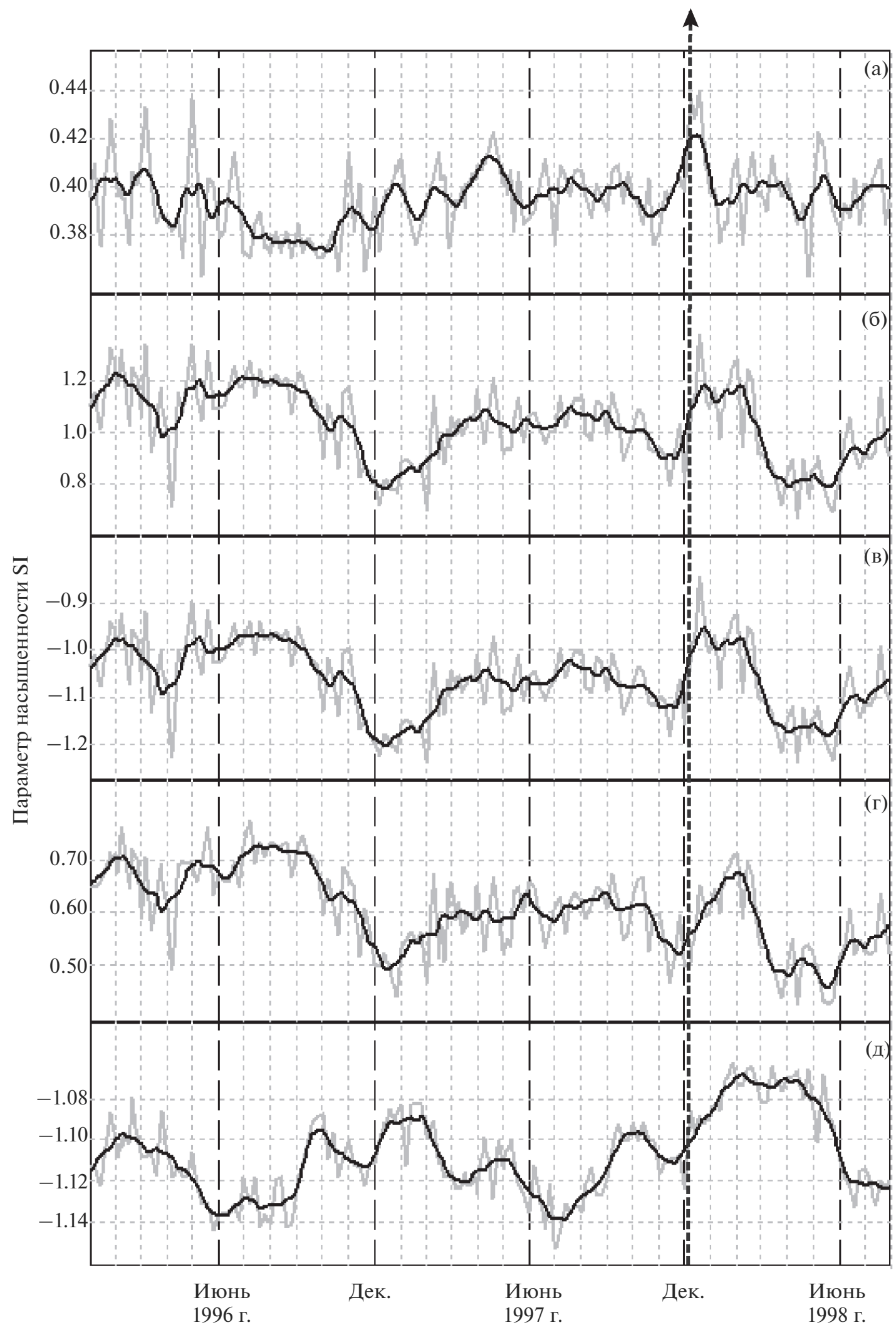

Рис. 6. Изменение насышенности подземной воды в скважине ГК-15, ст. Верхняя Паратунка к каолиниту (а), Самонтмориллониту (б), Na-монтмориллониту (в), кальциту (г), ангидриту (д) в 1996-1998 гг. Черными линиями показано осреднение расчетных значений индексов насыщенности в скользящем временном окне длиной 30 сут с шагом 3 сут. Вертикальная стрелка - землетрясение 5 декабря 1997 г., $M=7.8$. 


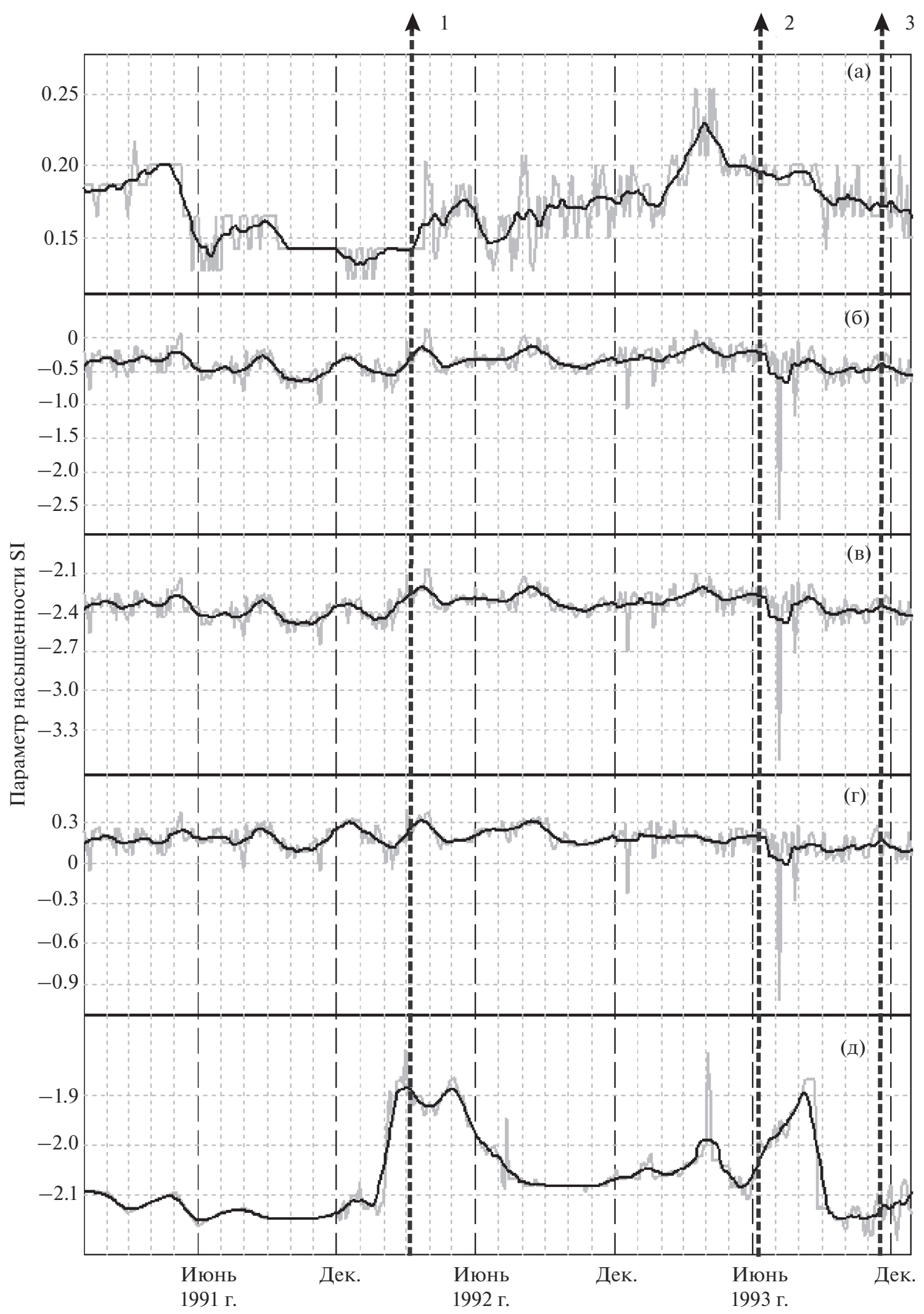

Рис. 7. Изменение насыщенности подземной воды скважины М-1 к каолиниту (а), Са-монтмориллониту (б), Naмонтмориллониту (в), кальциту (г), ангидриту (д) в 1991-1993 гг. Черными линиями показано осреднение расчетных значений индексов насыщенности в скользящем временном окне длиной 30 сут с шагом 3 сут. Вертикальные стрелки землетрясения: $1-2$ марта 1993 г., $M=6.8 ; 2-8$ июня 1993 г., $M=7.5 ; 3-13$ ноября 1993 г., $M=7.0$. 
вых дислокаций. Она вскрывает в диапазоне глубин 310-556 м напорные сульфатные натриевокальциевые воды с минерализацией 0.14 г/л и температурой $16^{\circ} \mathrm{C}$, распространенные в вулканогенно-осадочных отложениях поздненеогенового возраста. Дебит скважины - 1.5 л/с. По совокупности гидродинамических и гидрогеохимических признаков (сезонные изменения дебита и температуры воды, низкая минерализация) вода этой скважины относятся к гидродинамической зоне свободного водообмена.

В скв. М-1 перед землетрясениями (см. рис. 1) проявлялся гидрогеохимический предвестник в увеличении концентраций ионов $\mathrm{SO}_{4}^{2-}, \mathrm{Na}^{+}$и $\mathrm{Ca}^{2+}$ при уменьшении концентрации $\mathrm{HCO}_{3}^{-}$. При этом происходило увеличение минерализации воды до 20\% [Копылова и др., 1994; Копылова, Болдина, 2012].

Станция Верхняя Паратунка. Скважины ГК-5, ГК-15, ГК-17 и ГК-44 выводят на поверхность азотные термальные воды, распространенные на глубинах 125-1200 м в пределах структурных депрессий рр. Паратунка и Карымшина. Все четыре скважины работают в крановом режиме, и большую часть времени излив из них не осуществляется (перекрыт заглушкой). При отборе проб воды заглушки открываются. Воды по составу хлоридно-сульфатные и сульфатные натриевые с $M=0.4-1.5$ г/л [Копылова и др., 1994; Хаткевич, Рябинин, 2004].

Подземные воды всех наблюдательных скважин являются напорными, поступающими с различных глубин: скв. ГК-1 - 400-1260 м; скв. М-1 $310-556$ м; скв. Г-1 - 1710-2424 м, скв. ГК-5, ГК-15, ГК-17, ГК-44 - 125-1200 м. Для них характерны трещинный и трещинно-жильный типы циркуляции в уплотненных слабометаморфизованных вулканогенно-осадочных и терригенных отложениях позднемелового-неогенового возраста. Воды источников станции Пиначево являются безнапорными (П-3, П-1) и слабонапорными (П-2/1 и П-2/2), для них характерен порово-трещинный и трещинный типы циркуляции в отложениях зоны выветривания экструзивного массива андезидацитов и рыхлых покровных отложений четвертичного возраста. Формирование химического состава воды водопроявлений станций Пиначево, Морозная и Хлебозавод осуществляется в естественных условиях без влияния техногенных факторов и внутригодовой сезонности водного питания. В изменениях состава воды скважин станции Верхняя Паратунка влияние эксплуатации Паратунского месторождения термальных вод проявляется весьма слабо вследствие их значительной удаленности от районов водозабора.

\section{РЕЗУЛЬТАТЫ ИССЛЕДОВАНИЯ}

\section{Характеристика водопроявлений по условиям} формирования и химическому составу воды

Химический состав подземных вод скважин и источников весьма разнообразен (см. табл. 1, 2, рис. 2), что определяется сложным сочетанием природных факторов, влияющих на процессы его формирования в условиях Восточной Камчатки [Гидрогеология ..., 1972]. Особенности химического состава вод, такие как минерализация, преобладающие анионы и катионы, газы и концентрации микрокомпонентов, определяются, главным образом, их приуроченностью к различным гидродинамическим зонам водообмена. Важную роль также играют локальные геолого-тектонические условия, такие как состав водовмещающих пород, характер гидрогеологической структуры, степень ее закрытости/открытости и гидродинамической связи с подземными водами в приповерхностных и глубинных зонах. Эти факторы, а также история развития районов станций с присущими ей особенностями эволюции состава подземной воды определяют современный химический состав воды режимных водопроявлений за счет поступления минеральных компонентов в подземную воду из водовмещающих пород, из смежных водоносных горизонтов и зон повышенной трещиноватости.

Степень гидродинамической связи с "глубинными” гидротермами также влияет на особенности химического состава вод скважин и источников, расположенных в зонах разгрузки современных гидротермальных систем Пиначевской (ст. Пиначево) и Паратунской (ст. Верхняя Паратунка). Состав гидротерм в относительно изолированных фрагментах гидротермальных систем определяет гидрогеохимический фон подземных вод в районах их разгрузки за счет смешивания солоноватых и соленых вод зоны затрудненного водообмена с пресными водами зоны свободного водообмена. Для района ст. Пиначево такими “глубинными” водами являются азотно-метановые хлоридные кальциево-натриевые соленые воды, обогашенные широким набором микрокомпонентов. Их разгрузкой и смешиванием с пресными водами верхней гидродинамической зоны свободного водообмена объясняются аномалии повышенных концентраций $\mathrm{Cl}^{-}, \mathrm{Na}^{+}$, кремниевой кислоты, метана, гелия и др. геохимических индикаторов в подземных и поверхностных водах подножия Пиначевского экструзивного массива и бассейна р. Пиначевой [Поляк и др., 1965].

В наиболее прогретых частях Паратунской гидротермальной системы по данным бурения распространены азотные хлоридно-сульфатные и сульфатные кальциево-натриевые солоноватые воды с температурами до 100 и более ${ }^{\circ} \mathrm{C}$. Участки 
их концентрированной разгрузки и области рассредоточенной разгрузки за счет смешивания с водами из вышележащих горизонтов холодных пресных вод маркируются на поверхности повышенными температурами и концентрациям ионов хлора, сульфата, натрия и кремниевой кислоты в составе поверхностных и подземных вод [Манухин, Ворожейкина, 1976].

Среди рассматриваемых подземных вод по их гидрогеологическим особенностям, температуре и с учетом особенностей их химического состава выделены: 1 - безнапорные (грунтовые) поровотрещинные пресные холодные воды верхней гидродинамической зоны свободного водообмена (источники П-3 и П-1, ст. Пиначево); 2 - слабонапорные порово-трещинные и трещинные пресные субтермальные воды верхней гидродинамической зоны свободного водообмена (источники П-2/1 и П-2/2, ст. Пиначево); 3 - напорные трещинные и трещинно-жильные соленые субтермальные воды гидродинамической зоны затрудненного водообмена (скв. ГК-1, ст. Пиначево и скв. Г-1, ст. Хлебозавод); 4 - напорные трещинно-жильные ультрапресные субтермальные воды гидродинамической зоны свободного водообмена (скв. М-1, ст. Морозная); 5 - напорные трещинно-жильные пресные субтермальные воды зоны активного водообмена в пределах Паратунской гидротермальной системы (скважины ГК-44 и ГК-15, ст. Верхняя Паратунка); 6 - напорные трещинно-жильные солоноватые термальные воды зоны активного водообмена в пределах Паратунской гидротермальной системы (скважины ГК-17 и ГК-5, ст. Верхняя Паратунка).

В районе ст. Пиначево в верхней зоне свободного водообмена холодных вод распространены пресные, преимущественно, трещинные воды зоны экзогенной трещиноватости в андезидацитах и поровые воды в рыхлых покровных отложениях. В источниках П-3 и П-1 разгружаются холодные ультрапресные и пресные гидрокарбонатнохлоридные магниево-кальциевые и натриевые воды с минерализацией 126 и 409 мг/л и с температурами $6.2^{\circ} \mathrm{C}(\Pi-3)$ и $7.6^{\circ} \mathrm{C}(\Pi-1)$. Содержание кремния в водах составляет 15-16 мг/л и отмечается присутствие сульфат-иона до 4.8 мг/л. В источниках П-2/1 и П-2/2 разгружаются трещинные воды с температурой $10.3-11.1^{\circ} \mathrm{C}$ и минерализацией 934-955 мг/л, слабощелочные с рН 7.8-7.9, по составу гидрокарбонатно-хлоридные натриевые с 16-17\%-экв. долей магния и содержанием кремния до 17 мг/л при отсутствии сульфат-иона.

Воды источников характеризуются слабощелочными условиями геохимической среды с величинами Еh от 75 мВ (П-1) до -2...-3 мВ (П-2/1, П-2/2), показывающие различный вклад гидротерм, формирующихся в восстановительных условиях, в их водную разгрузку.
Трещинно-жильная слабощелочная (pH 8.9) ультрапресная $(M=0.13$ г/л) вода из скв. М-1, ст. Морозная с температурой $15.7^{\circ} \mathrm{C}$ по составу сульфатная натриево-кальциевая с содержанием кремния 5.8 мг/л, также формируется в верхней гидродинамической зоне свободного водообмена холодных вод. Для нее характерны окислительные условия геохимической среды с Eh 85 мB.

Субтермальные соленые трещинно-жильные воды скважины ГК-1, ст. Пиначево и скважины Г-1 ст. Хлебозавод формируются в зонах относительно затрудненного водообмена в пределах погруженных участков структурных депрессий. В скв. ГК-1 в слабо восстановительных условиях геохимической среды с $\mathrm{Eh}-88 \mathrm{MB}, \mathrm{pH} 7.5$ и присутствием в воде иона аммония (до 2.4 мг/л) разгружаются соленые воды с минерализацией 11.1 г/л, по составу хлоридные кальциево-натриевые, с содержанием кремния до 22.7 мг/л и повышенными концентрациями калия, лития, бора (16.3 мг/л). Наличие в составе воды высоких концентраций бария (11.7 мг/л) и стронция (79.1 мг/л) (см. табл. 2) указывает на возможность вторичного минералообразования сульфатов и карбонатов в подземных водах района ст. Пиначево. Повышенные температуры воды (на глубине 1200 м до $60^{\circ} \mathrm{C}$ ) и высокие концентрации кремния, бора и ряда микрокомпонентов свидетельствуют о существенной доле глубинной термальной составляющей в воде скв. ГК-1.

В скважине Г-1, ст. Хлебозавод в слабо восстановительных условиях среды с Eh-16 мВ разгружаются соленые хлоридные натриевые воды с минерализацией 12.6 г/л, температурой $14.3^{\circ} \mathrm{C}$ и pH 9.9 с содержанием иона аммония 8.9 мг/л, фтора до 3.8 мг/л, калия до 48 мг/л и отсутствием кремния. В микрокомпонентном составе в повышенных концентрациях обнаружены литий (3.2 мг/л), бор (21.4 мг/л), ванадий, галлий, германий, рубидий, стронций (25.3 мг/л), сурьма, бром, барий, редкоземельные элементы, таллий и свинец (см. табл. 2).

Трещинно-жильные субтермальные воды скважин ГК-44 и ГК-15 и термальные воды скважин ГК-17 и ГК-5, ст. Верхняя Паратунка формируются в зоне активного водообмена термальных вод [Манухин, 1971]. Субтермальные трещинножильные воды из скв. ГК-44 с температурой воды $T=20^{\circ} \mathrm{C}$, и из скв. ГК-15 $\left(T=25.5^{\circ} \mathrm{C}\right)$ являются пресными с минерализацией 0.41 г/л и 0.77 г/л, соответственно, слабощелочными с рН 8, по составу - сульфатными кальциево-натриевыми с присутствием хлора 15-19\%-экв., с содержанием кремния 9.0 и 9.6 мг/л, присутствием фтора (0.51.6 мг/л), лития (0.26-0.37 мг/л), бора, галлия, мышьяка, молибдена, сурьмы, вольфрама и свинца.

В скважинах ГК-17 и ГК-5 разгружаются трещинно-жильные термальные воды с температу- 
рами $37.4^{\circ} \mathrm{C}$ и $75.5^{\circ} \mathrm{C}$, щелочные (рН 8.8-8.9). Их минерализация составляет 0.98 г/л и 1.47 г/л. По составу воды хлоридно-сульфатные натриевые и сульфатные кальциево-натриевые с долей хлора $16 \%$-экв. и с содержанием кремния 20.7 и 25.6 мг/л.

В трещинно-жильных термах ст. Верхняя Паратунка присутствуют в повышенных содержаниях фтор (от 3.75 до 3.02 мг/л), литий (от 0.66 до 0.87 мг/л), бор (до 5 мг/л), галлий, германий, мышьяк, рубидий, молибден, цирконий, сурьма, цезий, вольфрам, свинец. Отличительной особенностью этих вод также являются щелочные свойства геохимической среды и рост концентраций сульфата и хлор-иона с увеличением температуры воды и глубины скважин.

Типизация подземных вод. На диаграммах химического состава вод из опробованных водопроявлений (см. рис. 2) выделены три группы подземных вод: группа I - пресные гидрокарбонатнохлоридные магниево-натриевые и натриевые воды зоны свободного водообмена в районе Пиначевского экструзивного массива; группа II - соленые хлоридные кальциево-натриевые и натриевые воды в зонах относительно затрудненного водообмена в погруженных участках структурных депрессий; группа III - сульфатные натриево-кальциевые холодные ультрапресные и сульфатные кальциево-натриевые пресные и солоноватые термальные воды в пределах Начикинской зоны складчато-глыбовых дислокаций.

В зоне затрудненного водообмена в погруженных участках депрессий характерным показателем состава соленых вод скважин ГК-1 и Г-1 (группа II) является присутствие иона аммония как признака восстановительной среды (см. табл. 1). Накопление в таких водах основных макрокомпонентов - натрия и хлора - сопровождается увеличением концентраций лития, фтора, бора и брома. Вместе с тем, прослеживается дифференциация катионов в зависимости от состава вмещающих пород. Так, подземная вода из скв. Г-1 из пород позднемелового возраста является хлоридной натриевой с присутствием сульфат-иона и повышенных концентраций бора, лития, фтора, брома и отсутствием кремния и железа. При этом отношение $\mathrm{Cl} / \mathrm{Na}$ для этой воды близко $\mathrm{K}$ единице, что позволяет предполагать влияние морских растворов на формирование ее химического состава. Для соленых вод скв. ГК-1, также формирующихся в верхнемеловых отложениях, характерны отсутствие сульфат-иона и хлоридный кальциево-натриевый состав с присутствием брома, бора, лития, железа (до 2.71 мг/л) и кремния (19.9 мг/л). Особенности состава воды скв. ГК-1 могут быть обусловлены деятельностью сульфатредуцирующих бактерий и восстановлением серы в восстановительных условиях среды при наличии органического вещества [Гидрогеология ..., 1972].

Химический состав всех трех выделенных групп вод также определяется характером взаимодействия воды с минералами вмещающих пород и стадийностью вторичного минералообразования [Шварцев, 1998, 2008; Шварцев и др., 2007], что можно проследить по состоянию равновесия вод с алюмосиликатными минералами (см. рис. 3) и по степени насыщенности вод алюмосиликатными, карбонатными и сульфатными минералами (табл. 3, см. рис. 4).

Из анализа диаграмм на рис. 3 следует, что взаимодействие рассматриваемых подземных вод с породами носит равновесно-неравновесный характер [Шварцев, 2008]. При этом расположение расчетных точек показывает, что подземные воды режимных водопроявлений находятся в различной степени насыщения вторичными алюмосиликатными и хемогенными минералами (кальцитом, сидеритом, доломитом и баритом) и, как правило, они не насыщены эндогенными минералами и ангидритом.

Грунтовые воды источников П-1 и П-3, формирующиеся в зоне свободного водообмена, при их взаимодействии с алюмосиликатными породами находятся на начальных стадиях развития системы вода-порода. Они насыщены каолинитом, $\mathrm{Ca}-, \mathrm{Mg}$-монмориллонитами и находятся в состоянии равновесия с Na-монтмориллонитом. Пресные трещинные воды источников П-2/1 и П-2/2 насыщены Ca-, $\mathrm{Mg}$-, $\mathrm{Na-монтмориллони-}$ тами и достигают равновесия с К-монтмориллонитом. Кроме того они находятся в равновесии с хемогенными минералами - сидеритом, доломитом.

На диаграммах полей устойчивости алюмосиликатных минералов (см. рис. 3) прослеживается направленность эволюции состава хлоридных вод группы II и сульфатных вод группы III от равновесия вод с каолинитом к равновесию с монтмориллонитами и первичными минералами. В поле устойчивости альбита и калиевого полевого шпата располагаются точки, соответствующие термальным сульфатным водам и соленым хлоридным водам.

Данные по химическому составу воды и термодинамические расчеты показывают, что воды режимных скважин и источников находятся на разных стадиях взаимодействия в системе вода-порода и являются насыщенными каолинитом, Сa-, $\mathrm{Mg}-$, Na-, K-монтмориллонитами, кальцитом, баритом, и они околоравновесны с сидеритом. Также для них можно предполагать, что по мере эволюционного развития взаимодействия системы вода-порода наблюдается усложнение спектра вторичных новообразующихся минералов и достижение равновесия вод с хемогенными ми- 


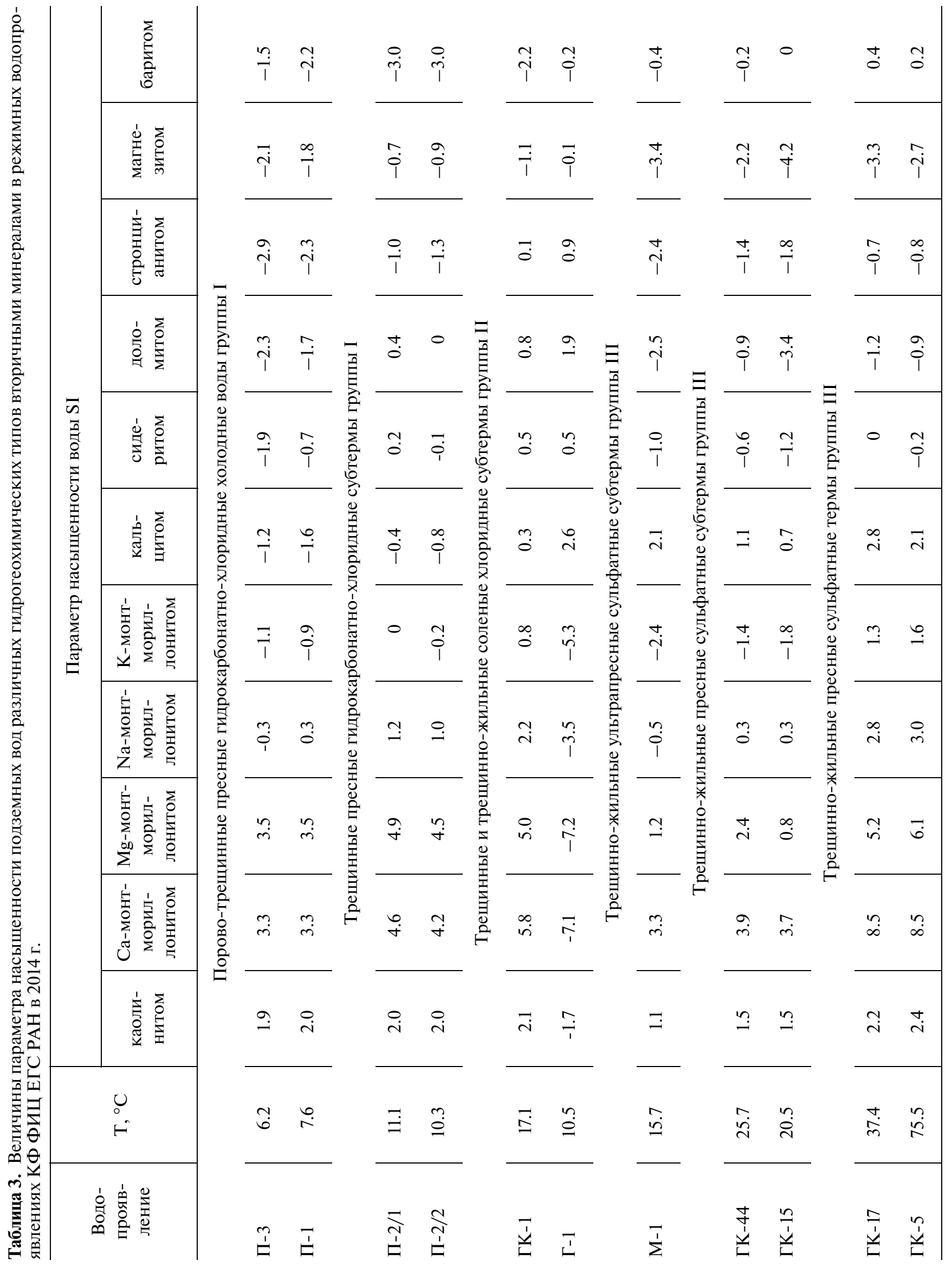


нералами - кальцитом, сидеритом, доломитом и баритом. Кроме того, по мере увеличения времени взаимодействия системы вода-порода от вод группы I, характеризующихся наименьшими временами такого взаимодействия, к водам групп II и III повышаются значения параметров насыщенности новообразующимися минералами, что особенно характерно для подземных вод в гидродинамической зоне затрудненного водообмена из скважин ГК-1 и Г-1 (см. рис. 4).

\section{Вариации насыщенности подземных вод вторичными минералами в связи с сильными землетрясениями}

На рис. 5-7 приводятся примеры реконструкции изменений показателей насыщенности вторичными минералами (SI) вод группы I (ист. П-1) и группы III (скважин ГК-15, M-1) в сопоставлении с произошедшими сильными землетрясениями (см. рис. 1). Приведенные графики изменения величин SI во времени имеют оценочный (качественный) характер, так как в расчетах использовались термодинамические параметры для реакций взаимодействия воды с минералами при температуре $25^{\circ} \mathrm{C}$ [Гарелс, Крайст, 1968]. При таком подходе к анализу вариаций индексов насыщенности в сопоставлении с землетрясениями, показательными являются амплитуды и общий характер изменения величин SI.

В изменениях показателей SI для вод ист. П-1 и скв. ГК-15 прослеживается его рост в течение первых месяцев после землетрясений, произошедших на эпицентральных расстояниях 120-300 км от станций и сопровождавшихся сотрясениями с интенсивностью до 5-6 баллов по шкале MSK-64 (постсейсмический эффект). После достижения максимумов происходило плавное уменьшение величин SI с последующей стабилизацией его значений.

На стадиях подготовки землетрясений в водах ист. П-1, скв. ГК-15 и др. водопроявлений изменения насыщенности подземных вод вторичными минералами проявлялось весьма слабо. Исключение составляет скв. М-1, в воде которой перед землетрясением 2 марта 1992 г. в течение месяца наблюдается заметное увеличение индекca SI к ангидриту (см. рис. 7). Эффект увеличения насыщенности воды скв. М-1 ангидритом ранее был выделен в новый вид гидрогеохимического предвестника, обусловленного изменениями в процессах взаимодействия в системе вода-порода [Копылова и др., 2014]. За два месяца до землетрясения 8 июня 1993 г. также наблюдалось резкое кратковременное увеличение насыщенности подземной воды скв. М-1 к ангидриту (см. рис. 7). Повышенные величины SI к ангидриту также фиксировались в течение двух месяцев после зем- летрясений 2 марта 1992 г. и 8 июня 1993 г. (постсейсмический эффект).

\section{ОБСУЖДЕНИЕ РЕЗУЛЬТАТОВ}

Впервые выполнено специальное гидрогеохимическое опробование подземных вод 11-ти режимных водопроявлений на территории Петропавловского геодинамического полигона для изучения особенностей формирования состава воды в системе вода-порода; предложена типизация подземных вод по химическому составу с учетом физико-химических свойств вод, их приуроченности к различным гидродинамическим зонам водообмена и локальных гидрогеологических условий. Выделены три группы подземных вод: группа I - порово-трещинные и трещинные грунтовые воды зоны активного водообмена холодных пресных вод преимущественно гидрокарбонатно-хлоридного состава, группа II - трещинные и трещинно-жильные соленые субтермы зоны затрудненного водообмена преимущественно хлоридного состава, группа III - трещинножильные холодные и термальные пресные и солоноватые воды преимущественно сульфатного состава зон свободного и активного водообмена.

Термодинамические расчеты показали, что воды скважин и источников находятся на разных стадиях взаимодействия в системе вода-порода [Шварцев и др., 2007]. Ультрапресные холодные воды группы I из источников П1 и П3 находятся в состоянии равновесия вод с каолинитом, Са- и Mg-монтмориллонитами, т.е. на стадии формирования кремнистого геохимического типа кальциевого и магниевого подтипов, по [Шварцев и др., 2007]. В пресных водах субтерм из источников П-1/2 и П-2/2 достигается равновесие вод также с Na-монтмориллонитом (кремнисто-натриевый подтип), кальцитом и сидеритом, что является показателем формирования собственно кремнистого карбонатно-кальциевого геохимического типа вод.

Повышение минерализации вод, концентраций кремния, хлора, натрия, калия, а также ряда микрокомпонентов в водах верхней гидродинамической зоны свободного водообмена связано с увеличением времени взаимодействия системы вода-порода и увеличением глубины проникновения подземных вод. Факторами времени и глубины фильтрации подземных вод объясняется рост количества минералов, равновесных с водой, а также повышение температуры и уменьшение значений окислительно-восстановительного потенциала, характеризующих смену геохимической обстановки на менее окислительную.

На примере соленой воды из скв. ГК-1, формирующейся в условиях затрудненного водообмена (группа II), прослеживается ее способность 
к накоплению ряда химических элементов вследствие увеличения времени взаимодействия в системе вода-порода в восстановительных условиях геохимической среды. В этой воде достигается равновесие с К-монтмориллонитом (кремнистокалиевый подтип), кальцитом, сидеритом и доломитом и формируется кремнистый карбонатнокальциевый геохимический тип вод. В таких условиях в подземной воде повышаются концентрации

$\mathrm{Si}, \mathrm{Cl}, \mathrm{Br}, \mathrm{B}, \mathrm{NH}_{4}^{+}$, Li, B, Si, Na, Ca, K, а также Mn, $\mathrm{Fe}, \mathrm{Ge}, \mathrm{As}, \mathrm{Br}, \mathrm{Rb}, \mathrm{Sr}$ и Ва (см. табл. 1, 2).

Соленые воды скв. Г-1 сформировались в условиях длительного взаимодействия подземной воды со слабометаморфизованными, преимущественно, морскими отложениями (филлитовидные, битуминизированные сланцы, аргиллиты). Для них характерно отношение $\mathrm{Cl} / \mathrm{Na} \approx 1$ и равновесие с карбонатными вторичными минералами - кальцитом, доломитом, стронцианитом, а также околоравновесное состояние по отношению к сидериту.

Сульфатные воды гидродинамической зоны свободного водообмена субтермальных (скв. М-1) и зоны активного водообмена термальных вод из скважин станции Верхняя Паратунка (группа III) относятся к кремнистому карбонатно-кальциевому (содовому) геохимическому типу вод на разных стадиях его проявления. Они характеризуются последовательным достижением равновесия с $\mathrm{Ca}-, \mathrm{Mg}-, \mathrm{Na}-$ и K-монтмориллонитами и кальцитом. Так, для ультрапресной воды из скв. М-1 отмечается ее равновесие с каолинитом, Са- и Mg-монтмориллонитами, кальцитом и еe соответствие кремнистому магниевому подтипу. В пресных субтермах из скважин ГК-44 и ГК-15 достигается равновесие вод также с $\mathrm{Na-монтморил-}$ лонитом и кальцитом, что является показателем формирования кремнистого натриевого подтипа. С увеличением времени взаимодействия системы и температуры в пресных и солоноватых термах скважин ГК-17 и ГК-5 достигается равновесие также с К-монтмориллонитом, кальцитом и формируется кремнистый калиевый подтип кремнистого карбонатно-кальциевого (содового) геохимического типа с начальной стадией формирования вторичных сульфатных минералов (барита).

В сульфатных водах группы III, одновременно с увеличением времени взаимодействия подземных вод с вмещающими отложениями, их температурой и увеличением глубины фильтрации, последовательно наращивается число равновесных с водой глинистых минералов, происходит изменение геохимической обстановки на менее окислительную; повышаются концентрации сульфатов, $\mathrm{Na}, \mathrm{Si}, \mathrm{F}, \mathrm{Li}, \mathrm{B}$, а также As, Ge, Br, Mo, Sb, Rb, $\mathrm{Cs}, \mathrm{W}, \mathrm{Th}$ (см. табл. 1, 2). Можно предположить, что для вод группы III с увеличением степени их насыщенности вторичными минералами созда- ются более благоприятные условия для прослеживания гидрогеохимических предвестников землетрясений.

По мере эволюционного развития системы вода-порода наблюдается усложнение спектра вторичных новообразующихся минералов и достигается равновесие вод с хемогенными минералами - кальцитом, сидеритом, доломитом, баритом. Кроме того, по мере увеличения времени взаимодействия системы вода-порода, что особенно характерно для вод скважин ГК-1, Г-1, ГК-17 и ГК-5, повышаются значения параметров насыщенности новообразующимися минералами (см. табл. 3, рис. 4).

После сильных землетрясений 1992-1993 и 1997 гг. происходило увеличение насыщенности подземных вод вторичными минералами (см. рис. 5, 6). Это указывает на изменение взаимодействия в системах вода-порода при таких землетрясениях. Особенно ярко постсейсмический эффект проявился в связи с землетрясением 2 марта 1992 г., перед которым также был выделен новый вид геохимического предвестника в форме увеличения насыщенности подземной воды из скв. М-1 ангидритом в течение месяца (см. рис. 7) [Копылова и др., 2014].

Принимая во внимание специфику нового вида гидрогеохимического предвестника, рассмотрим изменение насыщенности вод ангидритом и баритом в термальных водах скважин ст. Верхняя Паратунка, которые также относятся к группе III (см. табл. 3, 4). Видно, что при переходе от ультрапресных вод к солоноватым, с увеличением температуры подземных вод, их минерализации и, соответственно, времени взаимодействия системы вода-порода, повышается насыщенность вод ангидритом и баритом, а также достигается равновесие вод с баритом, что указывает на возможность вторичного минералообразования сульфатов в водах группы III. По данным [Наумов, Сергеева, 2015] в скважинах ст. Верхняя Паратунка происходит отложение твердого осадка, в составе которого преобладают в различной степени гидратированные сульфаты кальция с присутствием кремнезема и алюмосиликатов.

Отсутствие ярких проявлений гидрогеохимических предвестников в водах скважин ст. Верхняя Паратунка в случае произошедших землетрясений, включая наиболее сильное землетрясение 5 декабря 1997 г. (см. рис. 1, 6), может быть связано с негативным влиянием кранового режима при проведении режимных наблюдений. Данные опробования (см. табл. 1, 2) позволяют предполагать, что воды из скважин ст. Верхняя Партунка находятся на особом этапе формирования их состава - в зоне умеренного раскрытия блоковой структуры Паратунского грабена на глубине около 1 км при поступлении гидротерм из зоны вос- 
Таблица 4. Изменение насыщенности термальных вод скважин станции Верхняя Паратунка сульфатными минералами по данным опробования в 2014 г.

\begin{tabular}{c|c|c|c}
\hline Скважина & Минерализация, мг/л & $\begin{array}{c}\text { Насыщение баритом } \\
\text { (параметр насыщенности SI) }\end{array}$ & $\begin{array}{c}\text { Насыщение ангидритом } \\
\text { (параметр насыщенности SI) }\end{array}$ \\
\hline ГК-44 & 407 & -0.225 & -1.690 \\
ГК-15 & 773 & 0.021 & -1.113 \\
ГК-17 & 1469 & 0.399 & -0.610 \\
ГК-5 & 979 & 0.204 & -1.311 \\
\hline
\end{tabular}

становительной геохимической среды, имеющей, по-видимому, гидросульфидный исходный состав вод с присутствием лития, фтора, бора. Расчеты показывают, что воды из этих скважин характеризуются высокой насыщенностью сульфатными минералами, вплоть до барита (см. табл. 4).

Как указывалось выше, скважины ст. Верхняя Паратунка работают в крановом режиме, и в вариациях состава их вод эффекты сильных землетрясений либо отсутствовали, либо проявлялись весьма слабо. Вместе с тем, убедительным примером проявления предвестников в воде группы III является скв. М-1, функционирующая в условиях свободного самоизлива. Не только в скв. М-1, но и в скважинах ГК-1 и Г-1 (группа вод II), разгрузка воды осуществляется свободным самоизливом, и во всех этих водах гидрогеохимические предвестники проявлялись на стадиях подготовки сильных землетрясений [Хаткевич, Рябинин, 2004]. Выполненный анализ условий формирования и геохимического облика сульфатных вод группы III позволяет предполагать, что эти воды и, соответственно, скважины ст. Верхняя Паратунка, могли бы быть не менее информативными для поиска гидрогеохимических предвестников, чем соленые хлоридные воды зоны замедленного водообмена (скв. ГК-1 и Г-1, группа вод II) при условии обеспечения их естественного гидродинамического режима.

\section{ЗАКЛЮЧЕНИЕ}

С использованием фундаментальных закономерностей формирования вторичных гидрогенно-минеральных комплексов, последовательно сменяющих друг друга в различных геохимических обстановках [Шварцев, 2008; Шварцев и др., 2007], показаны новые возможности рассмотрения особенностей режимных водопроявлений, используемых для поиска гидрогеохимических предвестников, в зависимости от насыщенности подземных вод первичными и вторичными породообразующими минералами.

Рассмотрены гидрогеохимические особенности подземных вод режимных водопроявлений Петропавловского полигона и выполнена их типизация с учетом физико-химических парамет- ров и локальных гидрогеологических условий приуроченности к различным гидродинамическим зонам водообмена, составу водовмещающих пород и характеру циркуляции. Определение генетической взаимосвязи выделенных типов подземных вод, находящихся на различных стадиях формирования их химического состава, с геохимическими типами выветривания, длительностью взаимодействия вод с горными породами и глубиной их фильтрации в сопоставлении с данными режимных наблюдений дает новые возможности для оценки информативности скважин и источников при поиске и изучении геохимических эффектов сейсмичности.

На примере отдельных водопроявлений прослежены изменения насыщенности подземных вод вторичными минералами во времени. Обнаружено, что в результате сильных землетрясений с величинами магнитуд порядка 7 и более, сопровождавших в районах наблюдательных станций сотрясениями с интенсивностью $I=5-6$ баллов, насыщенность подземных вод вторичными минералами увеличивается. На стадиях подготовки таких землетрясений изменение насыщенности подземных вод вторичными минералами проявляется в меньшей степени, по сравнению с эффектом роста насыщенности при воздействии сейсмических волн.

Приведено обоснование необходимости проведения режимных гидрогеохимических наблюдений на скважинах станции Верхняя Паратунка в условиях естественного самоизлива.

Работа выполнена в рамках плановых тем НИР КФ ФИЦ ЕГС РАН (рег. № АААА-А16116070550057-7, № AAAA-A16-116070550059-1).

\section{СПИСОК ЛИТЕРАТУРЫ}

Гаррелс Р.М., Крайст Ч.Л. Растворы, минералы, равновесия. М.: Мир, 1968. 368 с.

Геология СССР. Т. 31. Камчатка, Курильские и Командорские острова. Ч. 1. Геологическое описание / Ред. Власов Г.М., Белов М.Б. М.: Недра, 1964. 733 с.

Гидрогеология СССР. Т. 29. Камчатка, Командорские и Курильские острова. М.: Недра, 1972. 364 с.

Зверев В.П. Роль подземных вод в миграции химических элементов. М.: Недра, 1982. 182 с. 
Кирюхин А.В., Манухин Ю.Ф., Федоров С.А. и др. Геофлюиды Авачинско-Корякского вулканогенного бассейна, Камчатка // Геоэкология. Инженерная геология. Гидрогеология. Геокриология. 2015. № 4. С. 306-320.

Копылова Г.Н. Анализ влияния сейсмичности на режим Пиначевских термопроявлений на Камчатке (по результатам наблюдений в 1979-1988 гг.) // Вулканология и сейсмология. 1992. № 2. С. 3-18.

Копылова Г.Н., Сугробов В.М., Хаткевич Ю.М. Особенности изменения режима источников и гидрогеологических скважин Петропавловского полигона (Камчатка) под влиянием землетрясений // Вулканология и сейсмология. 1994. № 2. С. 53-70.

Копылова Г.Н., Болдина С.В. Аномальные изменения химического состава подземных вод в связи с Камчатским землетрясением 02.03.1992 г. $\left(M_{w}=6.9\right) / /$ Геофизические исследования. 2012. Т. 13. № 1. С. 39-49.

Копылова Г.Н., Копылова Ю.Г., Гусева Н.В. О генезисе и механизмах формирования гидрогеохимических аномалий в изменениях состава подземных вод под влиянием сейсмичности // Материалы региональной научной конференции “Вулканизм и связанные с ним процессы”, посвященной Дню вулканолога, 27-28 марта 2014 г. Петропавловск-Камчатский: ИВиС ДВО РАН, 2014. C. $181-186$.

Манухин Ю.Ф. О зонах водообмена геотермальных районов Камчатки // Вулканизм и глубины земли. М.: Наука, 1971. С. 219-224.

Манухин Ю.Ф., Ворожейкина Л.А. Гидрогеология Паратунской гидротермальной системы и условия ее формирования // Гидротермальные системы и тер- мальные поля Камчатки. Владивосток: ДВНЦ АН CСCP, 1976. С. 143-178.

Наумов А.В., Сергеева А.В. Гипс Верхне-Паратунского месторождения термальных вод // Проблемы комплексного геофизического мониторинга Дальнего Востока России. Труды Пятой научно-технической конференции Петропавловск-Камчатский, 27 сентября3 октября 2015 г. / Отв. ред. Чебров В.Н. Обнинск: ГС PAH, 2015. C. 86-90.

Поляк Б.Г., Вакин Е.А., Овчинникова Е.И. Гидрогеотермические условия вулканического района Камчатки (г. Петропавловск-Камчатский). М.: Наука, 1965. 95 с.

Федотов С.А., Гусев А.А., Чернышева Г.В., Шумилина Л.С. Сейсмофокальная зона Камчатки (геометрия, размещение очагов землетрясений и связь с вулканизмом) // Вулканология и сейсмология. 1985. № 4. С. 91-107.

Хаткевич Ю.М., Рябинин Г.В. Гидрогеохимические исследования на Камчатке // Комплексные сейсмологические и геофизические исследования Камчатки. Петропавловск-Камчатский: Камчатский печатный двор, 2004. С. 96-112.

Швариев С.Л. Гидрогеохимия зоны гипергенеза. М.: Недра, 1998. 366 с.

Шварцев С.Л. Фундаментальные механизмы взаимодействия в системе - горная порода и ее внутренняя геологическая эволюция // Литосфера. 2008. № 6. C. 3-24.

Шварцев С.Л., Рыженко Б.Н., Алексеев В.А. и др. Геологическая эволюция и самоорганизация системы водапорода. Т. 2. Система вода-порода в условиях зоны гипергенеза. Новосибирск: СО РАН, 2007. 389 с. 